\title{
Field Evaluation of Some Cassava Cultivars against the African Cassava Mosaic Disease in the Humid Forests of Cameroon
}

\author{
A. Mogo ${ }^{1}$, J. Fomekong Nopogwo $0^{2,3^{*}}$, E. L. Ngonkeu Mangaptche ${ }^{2,3}$, \\ R. Ghogomu Tamouh", E. Temgoua ${ }^{1}$, Fotso ${ }^{4}$, Noé Woin ${ }^{3}$, J. Djeugap Fovo', \\ M. Yemefack ${ }^{3}$, M. Tene Thierry ${ }^{5}$, D. Fotio ${ }^{3}$ and Hanna Rachid ${ }^{5}$ \\ ${ }^{1}$ University of Dschang, Cameroon. \\ ${ }^{2}$ University of Yaoundé I, BP 812 Yaoundé, Cameroon. \\ ${ }^{3}$ Institute of Agricultural Research for Development, IRAD, BP 2067, Cameroon. \\ ${ }^{4}$ University of Bamenda, Cameroon. \\ ${ }^{5}$ International Institute of Tropical Agriculture, Nigeria.
}

Authors' contributions

This work was carried out in collaboration between all authors. All authors read and approved the final manuscript.

Article Information

DOI: 10.9734/ARRB/2018/v30i330015 Editor(s):

(1) Dr. Rajeev Kumar, Department of Veterinary Public Health \& Epidemiology, Vanbandhu College of Veterinary Science \& A. $\mathrm{H}$, Navsari Agricultural University, India. (2) Dr. George Perry, Dean and Professor of Biology, University of Texas at San Antonio, USA. Reviewers

(1) Alex Abaca, National Crops Resources Research Institute (NaCRRI), Uganda. (2) Esraa Ashraf Ahmed ElHawary, Ain Shams University, Egypt. Complete Peer review History: http://www.sdiarticle3.com/review-history/45119

Original Research Article

Received 26 August 2018 Accepted 21 November 2018 Published 15 February 2019

\begin{abstract}
There is a considerable deficit in the annual production of cassava in Cameroon of about 31 million tons, and this has been mainly due to constraints related to pest attacks and most especially diseases like the African Cassava Mosaic Disease (ACMD). This study was therefore undertaken on three sites in the locality of Bityili (South Region of Cameroon), to determine amongst improved and local cassava cultivars those that provide resistance to the development of the ACMD. The severity and incidence of this disease was evaluated and its impact on cassava yield. In each site, cassava was grown in a randomized complete block design. The local cultivars (Ekobele and Ngon kribi) showed higher severity (76-100\%) and incidence of ACMD compared to the improved cultivars (TMS 92/0326 and TMS 96/1414) of $0-25 \%$ and $0-10 \%$, respectively. Strong inverse correlations
\end{abstract}


were observed between ACMD severity and yield performance, measured in terms of number of tubers/plant and weight of fresh tubers. The improved cultivars, TMS 92/0326 and TMS 96/1414, could, therefore, be recommended for large-scale planting in a bid to promote cassava production in the South Region of Cameroon.

Keywords: Cassava genotypes; African mosaic virus; resistant traits; Cameroon.

\section{INTRODUCTION}

Cassava (Manihot esculenta Crantz) is a perennial shrub of the Euphorbiaceae family, introduced in Africa by the Portuguese in the 16 th century [1]. Its global production is estimated at 250 million tons with about half of this coming from Africa [2]. In Cameroon, the annual production stands at 19 million tons [3], ranking the crop as the country's third most important cash food crop after coffee and cocoa [4]. Cassava procures food security in rural areas of Cameroon through subsistence agricultural practices. It has diverse usage, mainly as staple food crop (85\%), as well as in animal and several industrial sectors [5]. It is cropped in all the five agro ecological zones of Cameroon, but more intensely in the Southern part of the country (East, Center, South, Littoral, South-West, NorthWest and West administrative regions) where several; Cultivars are cultivated for their ease of cropping and tolerance to some biotic and abiotic constraints [6].

Even though, cassava cropping has some advantages, its annual demand remains high for a production of about 50 million tons, leading to a deficit of about 31 million tons [7]. The rather lower than expected yields could be attributed to agronomic constraints like low soil fertility, use of local less productive planting materials, diseases and attacks from pests like the White fly (Stictoccocus vayssierei Richard), the brown scaly insect (Phenacoccus manihoti, MatileFerrero), the cassava green mites (Mononychellus tanajoa Bondar) and cassava white flies (Bemisia tabaci Genn) [8,9]. Among the diseases, there are the brown leaf spots, root rot, cassava bacterial blight, anthracnose and most especially the African Cassava Mosaic Disease (ACMD), caused by the African cassava mosaic virus (ACMV) disseminated by the white flies. The ACMD is a real pandemic in Central Africa and accounts for $40-90 \%$ yield losses $[10,11]$.

Several methods have been used to minimise these losses with varying degrees of success [12]. The main objective of this study is for the field identification of cassava cultivars tolerant to the ACMV in the humid forests of Cameroon, and which can serve as bases in subsequent breeding programmes [13].

\section{MATERIALS AND METHODS}

\subsection{Site and Climatic Characteristics}

This study was conducted in three quarters in the Bityli village $\left(2^{\circ} 56^{\prime} \mathrm{N}, 11^{\circ} 11^{\prime} \mathrm{E}\right.$; Tyele, MinkonMingon and Mekoto) in the Mvila division, of the South region of Cameroon. This region is bordered to the East by the Congo Basin, to the West by the Gulf of Guinea where it is open to the Atlantic Ocean by a coastline of $380 \mathrm{~km}$, to the East by a vast equatorial domain with the Central African Republic, and to the South by the Republics of Equatorial Guinea, Congo and Gabon (Fig. 1). The region's predominant climate is the humid tropical forest with bimodal rainfall pattern, characterised by four distinct seasons; two dry (December-March and July-August) and two rainy (April-June and September-November). Annual mean rainfall is between $1500-2000 \mathrm{~mm}$ [14] with soils that are mostly hydromorphic or red/yellow ferralitic.

\subsection{Biological Materials}

The study was done on five cassava cultivars, three of which were improved (TMS92/0326, locally called "abui-pkwem", TMS96/1414 and 8034) and two were local ("Ekobélé » and "Ngon Kribi »).

Cuttings of improved cultivars were provided by IRAD (8034) and IITA (TMS92/0326 and TMS96/1414, locally called "Nkoh' Menzui"); and those of the local cultivars were obtained through participatory selection with farmers of healthy plants in their fields in each locality. The potential yields of the varieties ranged from $20-30$ tons/ha, $22-35$ tons/ha and $30-40$ tons/ha for the TMS 92/0326, TMS 96/1414 and 8034, respectively. The maturity period of the tested cultivars lasted for 12 months except for the 8034 that lasted for $9-12$ months. 


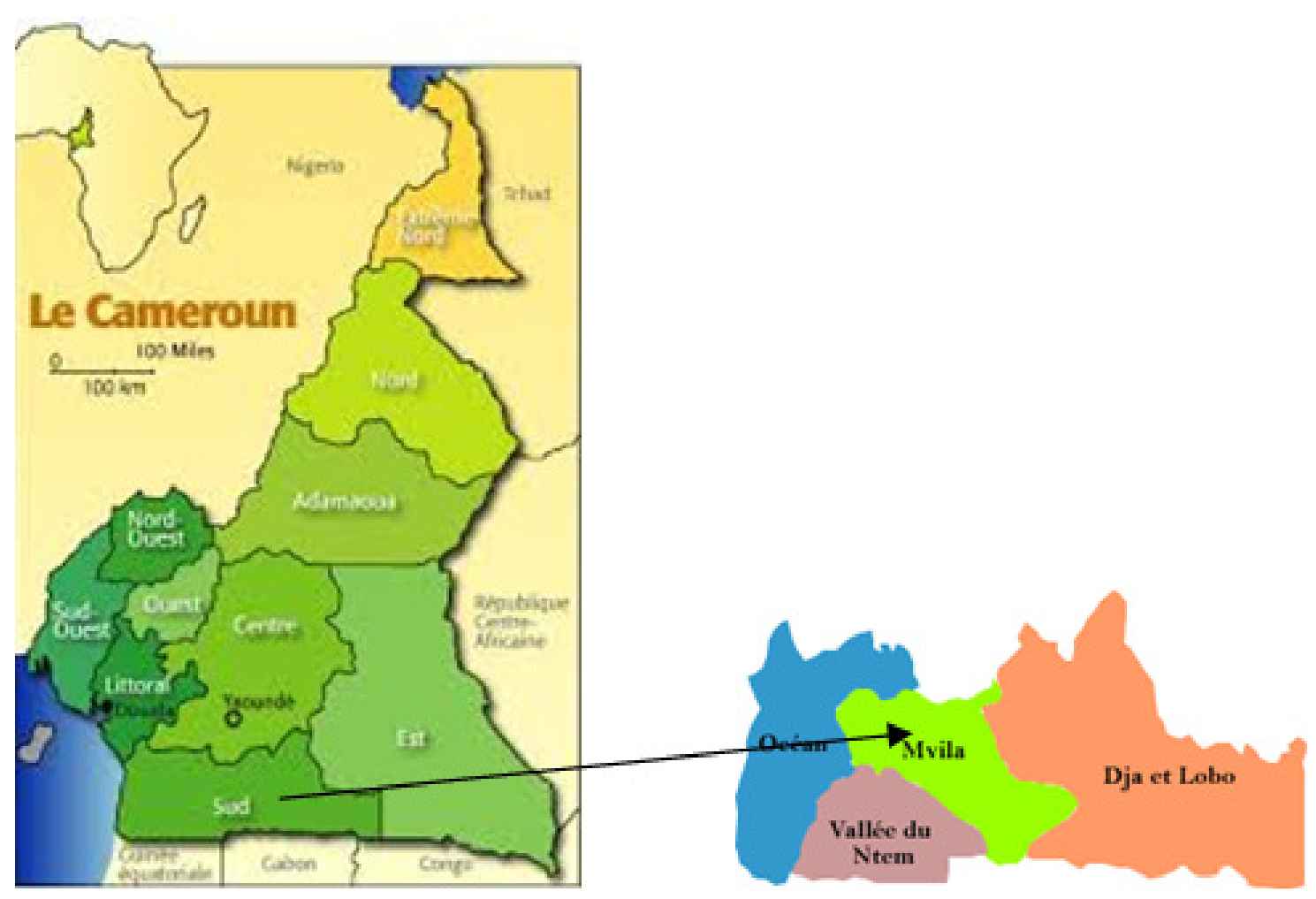

Fig. 1. Location of the experimental site

\subsection{Experimental Design and Treatments}

The experiment was conducted during the second cropping season of 2016 (June November). The crops were planted in a randomized complete block design with three replicates. Each site was made up of 30 experimental units of $5 \mathrm{~m} \times 10 \mathrm{~m}$ each. A guard row of $2 \mathrm{~m}$ was allowed between experimental units. Prior to the study, the fields used had been left under fallow for variable periods of time: MINKON MINGON (10 years), MEKOTO (3 years) and TYELE (2 years). The fields were manually cleared, and $30-\mathrm{cm}$ long cassava cuttings were sowed in equidistant rows and columns of $1 \mathrm{~m}$.

\subsection{Data Collection}

Agronomic data were collected fortnightly during the small dry season (August - September) in each site and the $6-7$ months plants evaluated for yields and for ACMD severity and incidence.

Visible symptoms were used to identify the presence of ACMD on each plant. The disease severity was determined as the percentage ratio of the attacked surface area of the cassava leaves to the total surface area considered for each plant. Here, the evolution of the disease on each crop was estimated using a scale from 1 to 5 where (1) was for no symptoms or disease, (2) for $1 \%-25 \%$ severity, (3) for $25 \%-50 \%$ severity, (4) for $50 \%-75 \%$ severity and (5) for $75 \%-100 \%$ severity [15].

The disease incidence on its part was assessed as the percentage ratio of the number of attacked plants to the total number of considered plants in each experimental unit.

During harvest, the number of tubers per plant, the weight of aerial biomass and the fresh tuber yield were assessed for each plant using a precision balance.

\subsection{Statistical Analyses}

Collected data were subjected to analyses of variance (ANOVA) using the General Linear with the Statistical Analyses System (SAS) software package (Version 9.2). Mean treatment values were separated using Turkey (PPDS) and Student-Newman-Keuls test at $5 \%$ probability level. 


\section{RESULTS}

\subsection{Severity of Cassava Mosaic Disease on Cassava Cultivars}

All cultivars showed but to different extents, a certain number of symptoms related to the viral attack.

Interaction between the site and the cultivars was highly significant $(p<0.0001)$, and CMD severity varied with the sites. Consequently, at the level of each site, there was a significant difference $(p<0.0001)$. Generally, trials with TMS 92/0326 and TMS 96/1414 had low ACMD severity, whereas the local cultivars were most affected as more than half of them had a severity of more than $75 \%$. The severity also varied with the sites as the ACMD was much higher in Tyele and Minkon Mingon, than in Mekoto (Table 2).

\subsection{CMD's Incidence on Cassava Cultivars}

Analyses of variances showed that ACMD was similar on all the three sites used, although the difference between cassava cultivars was highly significant $(p<0.0001)$. As shown in Fig. 2 , the attack was highest on the local varieties Ngon Kribi (94\%) and Ekobele (98\%) and least on the improved cultivars.

\subsection{Yield of Cassava Cultivars}

Table 2 indicates that cassava cultivars were significantly different with respect to the number of tubers per plant $(P<0.001)$, the aerial biomass per plant $(P=0.004)$ and the fresh tuber yields $(P$ $<0.001)$. The yield was not statistically different in different site.

\subsection{Effect of CMD on Cassava Yields}

The results presented in Fig. 3 showed a linear relationship between CMD's severity and the number of tubers per plant, as well as CMD's severity and tuber yields, and a negative and significant relation between ACMD severity and the number of tubers/plant. In effect, the number of tubers/ plant decreased by $26 \%$ when the severity increases by $1-25 \%$.

Table 1. Average severity of infected cassava cultivars per experimental site

\begin{tabular}{lllll}
\hline Cultivars & Scale & \multicolumn{3}{c}{ Sites } \\
\cline { 2 - 5 } & & Mekoto & Minkon Mingon & Tyele \\
\hline 8034 & 1 & 47.78 & 57.78 & 59.94 \\
& 2 & 12.22 & 18.89 & 23.31 \\
& 3 & 28.89 & 15.56 & 13.32 \\
TMS 92/0326 & 4 & 8.89 & 7.78 & 3.33 \\
& 5 & 2.22 & 0 & 0 \\
& 1 & 90 & 87.78 & 91.02 \\
& 2 & 10 & 11.11 & 8.88 \\
TMS 96/1414 & 3 & 0 & 1.11 & 0 \\
& 4 & 0 & 0 & 0 \\
& 5 & 0 & 0 & 0 \\
Ekobele & 1 & 80 & 87.78 & 79.92 \\
& 2 & 13.33 & 8.89 & 8.88 \\
& 3 & 6.66 & 3.33 & 4.44 \\
& 4 & 0 & 0 & 4.44 \\
Ngonkribi & 5 & 0 & 0 & 2.22 \\
& 1 & 1.11 & 0 & 0 \\
& 2 & 3.33 & 12.2 & 0 \\
& 3 & 4.44 & 42.22 & 15.54 \\
& 4 & 41.11 & 45.56 & 32.19 \\
& 5 & 50 & 0 & 52.17 \\
& 1 & 10 & 2.22 & 7.11 \\
& 2 & 6.67 & 1.11 & 5.55 \\
Scale: 1: no symptoms or & 5 & 15.56 & 11.11 & 32.19 \\
& 3 & 26.67 & 41.11 & 53.28 \\
\hline
\end{tabular}




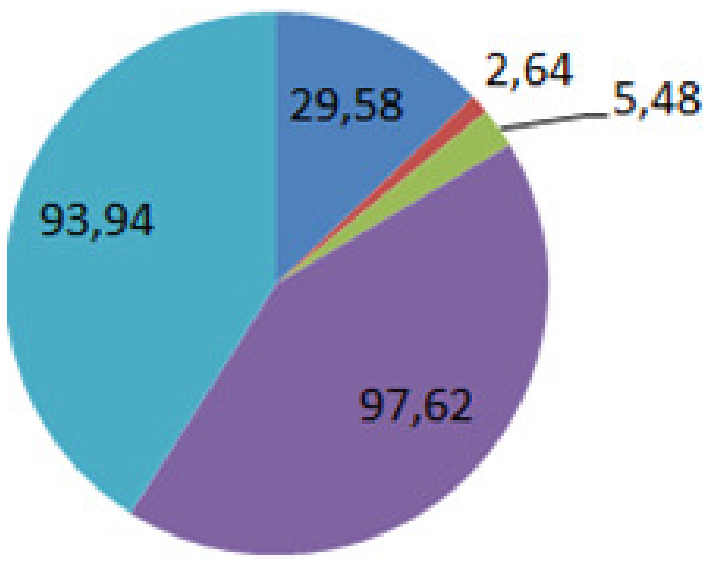

8034 92/0326 -96/1414 घEkobele \# Ngon Kribi

Fig. 2. CMD's incidence rate (\%) of cassava cultivars

Table 2. Tubers yield and aerial biomass of each cassava cultivars

\begin{tabular}{llll}
\hline Cultivars & Number of tubers /Plant & Biomass /Plant $\mathbf{~ K g )}$ & Tubers weight $(\mathbf{t} / \mathbf{h a})$ \\
\hline $\mathbf{8 0 3 4}$ & $3.02 \mathrm{ab}$ & $3.38 \mathrm{a}$ & $12.96 \mathrm{c}$ \\
$\mathbf{9 2 / 0 3 2 6}$ & $3.19 \mathrm{a}$ & $2.6 \mathrm{~b}$ & $14.9 \mathrm{a}$ \\
$\mathbf{9 6 / 1 4 1 4}$ & $3.79 \mathrm{a}$ & $2.62 \mathrm{~b}$ & $16.35 \mathrm{a}$ \\
Ekobele & $2 \mathrm{~b}$ & $1.97 \mathrm{bc}$ & $12.43 \mathrm{c}$ \\
NgonKribi & $2.65 \mathrm{~b}$ & $1.95 \mathrm{bc}$ & $13.08 \mathrm{~b}$ \\
Sign Dif. & $*$ & $*$ & $*$ \\
\hline
\end{tabular}

Figures followed by the same letters were not significantly different at $5 \%$ level probability

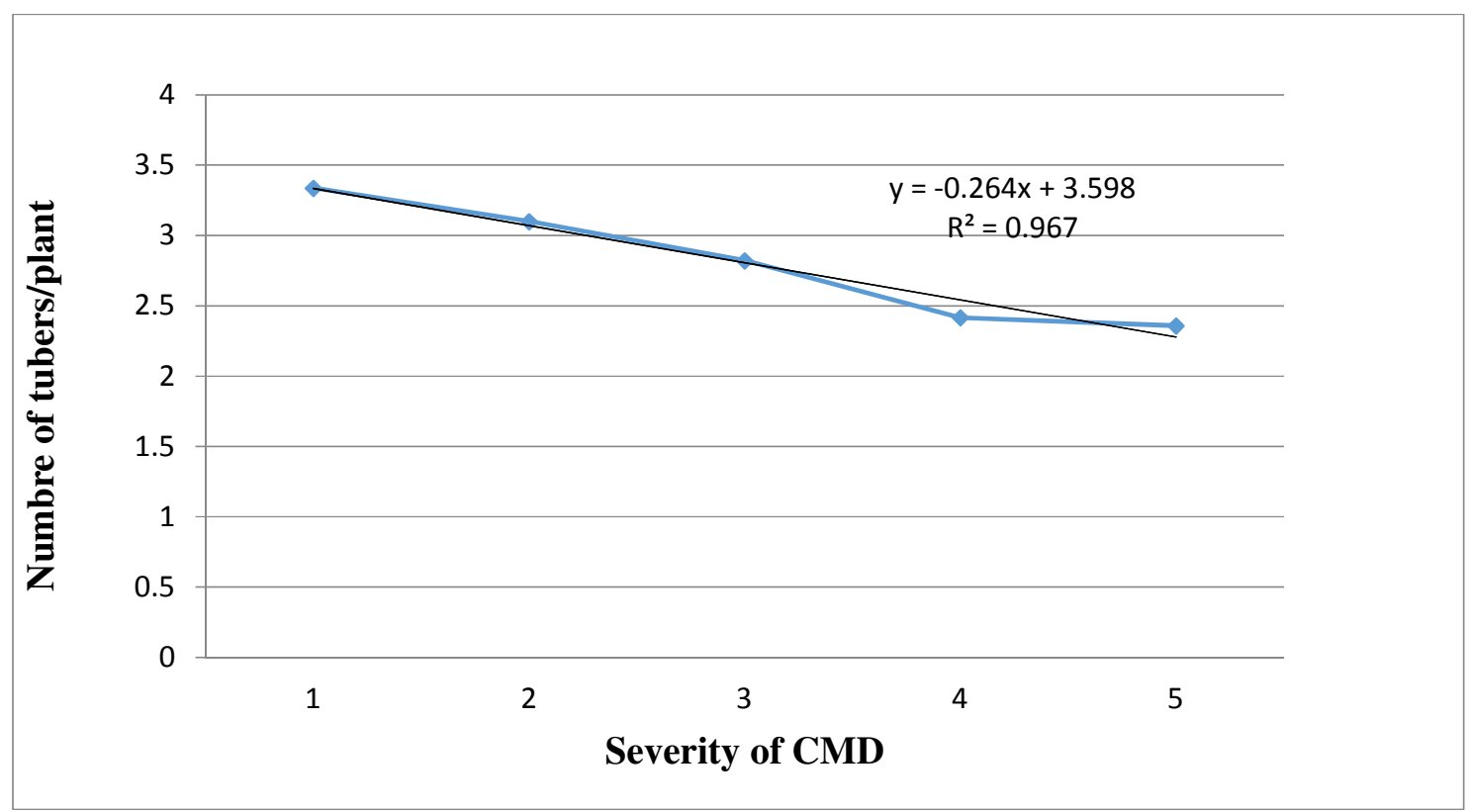

Fig. 3. Regression curve between the number of tubers/plant and the severity of CMD 


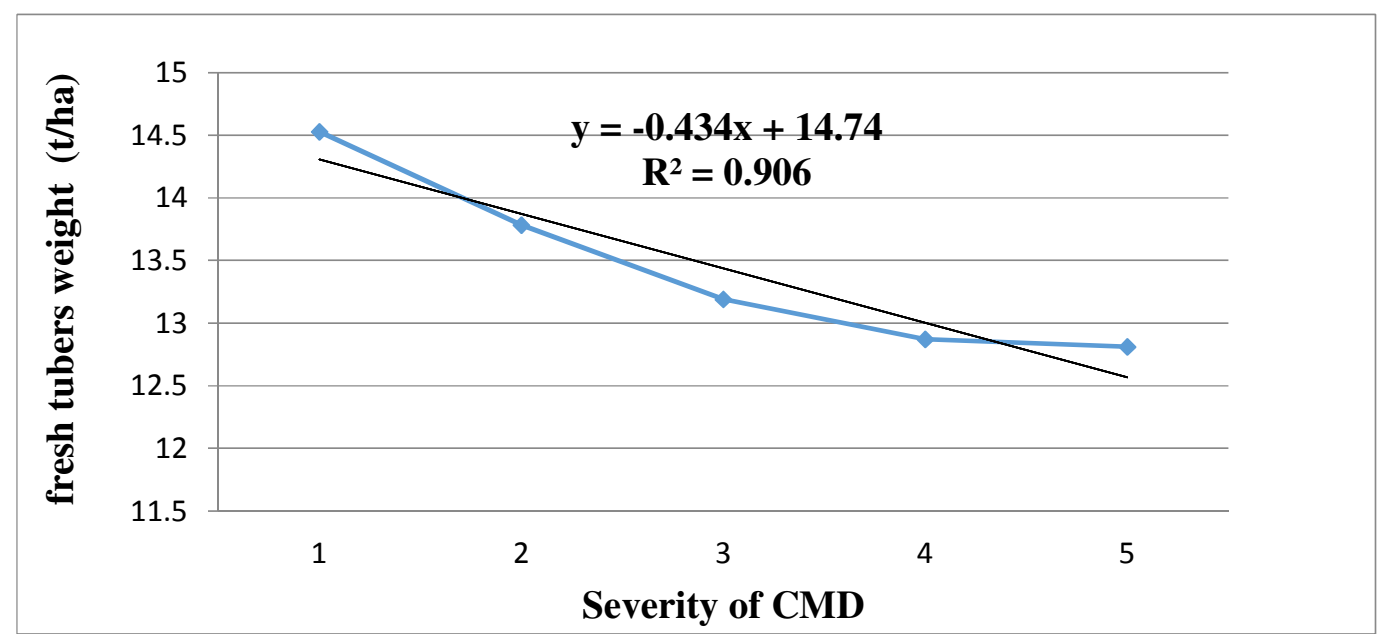

Fig. 4. Regression between fresh tubers yield (hectares) and the severity of CMD

Fig. 4, presenting the trend of fresh tuber yield with respect to the ACMD severity, shows a negative and highly significant regression between ACMD and unit fresh tuber weight. Here, an increase in the severity form $1-25 \%$ resulted in a decrease in the fresh tubers weight by $43.4 \%$.

\section{DISCUSSION}

All cultivars presented symptoms of the CMD although the improved cassava genotypes gave a weak severity and incidence rates for CMD, indicating that these genotypes (particularly TMS 92/0326 and TMS 96/1414) had resistant genes to withstand the attack. The susceptibility of local cultivars could most likely be genetic $[15,16,17]$. So the highest severity and incidence scores in the local cultivars can be attributed to the absence of resistant genes as in the case of improved cultivars with fewer severity and incidence. However, we should note that the biological material can be disease free but it capacity to resist infection remain identical as the mother plant from which it was collected [18]. Generally, when the infection is due to cassava cutting, it is the first leaves that are infected with severe severity of the virus [19], thus this infection of 7 months after planting could be due to white flies and not on the quality of the cutting; this is probably why incidence and severity of were very severe on susceptible cultivars, Ekobele and Ngon Kribi. In their recent study, the result obtained by several authors $[11,20]$ showed that the highest severity and incidence scores in the local cassava variety monocrop. This may be due to the early attacks of those cultivars by withflies population (Bemisia tabaci).
Strong severity of CMD observed at Minkon Mingon could be due to the reduced cropping land in that locality. Results from the study carried out by Fauquet et al. [21] revealed that, cassava cropped the same year is more infected in forest area than in savanna areas, this is probably due to the presence of potential host. Equally, as shown by Guthrie [18], the chance to have a severe severity for CMD is high in reduced cropped areas since the proximity of cassava plants increases the contamination rate. Whatever the year or clone considered, the contamination was always greater in the forest than in the savannah. All clones and years combined, the percentage of contamination varies from 10 to $88 \%$ in the forest zone while it varies from 1 to $20 \%$ in savanna zone, this during the same years [21].

Low yield registered by the different cultivars generally could solely due to the presence of rotten tubers as well as the fact that harvest took place during the dry season when the soil had become compact. Improved cultivars gave a yield relatively high as compare to the local cultivars. This is because these improved cultivars possess traits that confer them the capacity to produce much and better resist disease as compared to local cultivars that have lost their potential to resist diseases and became susceptible to disease particularly CMD which have significant impact on the yield or genetically have a low tubers production capacity. It is therefore from similar observation that, the [22] declared that improved cultivars resist to diseases and pests, and have a better tuber yield better than local cultivars. 
Yield evolution was inversely proportional to the increase in the degree of severity of CMD. An increase in severity from $1-25 \%$ brings about a decrease in fresh cassava tuber biomass by $43.4 \%$. [21] with different investigations confirms that, based on the increase in severity, yield losses can reach up to $24-78 \%$. Taken into consideration that the severity of local cultivars and an improved cultivar (8034) had severity of CMD higher in the leaves than in the cultivars TMS92/0326 and TMS961414. It is therefore evident that, a decrease in the cassava leave surface area followed by a decrease in the photosynthetic activities will result in a decrease in the crop to produce tubers; it has been demonstrated by Nkongolo [23] in his PhD thesis that CMD causes mosaic and leaf distortion, leading to defoliation and severe plant stunting. In the other hand, $[24,25]$ was also confirms that the leaf distortion caused by mosaic not only reduces the number of tubers, but also their growth and the ability of the tubers to grow and be mature for harvest.

\section{CONCLUSION}

This study evaluated the resistance of five cassava cultivars to the African cassava mosaic disease and showed that the disease severity and incidence were very weak on the improved cultivars (TMS 92/0326 and TMS 96/1414) as compared to the locals (Ekobele and NgonKribi). Similarly, improved cultivars had higher fresh tuber yields as compared to the locals. The regression between number of tubers per plant decreased considerably with an increase in the severity. Furthermore, a concomitant increase in ACMD severity led to a decrease in fresh tuber weight. Cultivars TMS 92/0326 and TMS 96/1414 could be recommended in the Southern part of Cameroon as they presented the lowest incidence and severity to CMD. Hence, the results presented here could serve as basic strategy in the search of long lasting solution to curb the presence of the ACMD on the cassava crop in the Tropics.

\section{ACKNOWLEDGEMENTS}

The authors gratefully acknowledge logistic and other support received in the framework of the Forest Savanna Sustainability Project Cameroon (FOSAS) funded by the Japanese Agency for International Cooperation (JICA) and its Coordinator, Dr. Foahom B. The editorial support of Mr Mballa T.A.N., Dr. Dongmo T., Dr.
Kenga R. and Dr. Ehabe E.E. are equally acknowledged.

\section{COMPETING INTERESTS}

Authors have declared that no competing interests exist.

\section{REFERENCES}

1. Maroya NG. Caractérisation morphologique des clones de manioc cultivés en Afrique de l'ouest et du centre (Bénin, Cameroun, Ghana et Nigéria). 1997;23.

2. Tolly LE. Amélioration de la commercialisation et de transformation du manioc au Cameroun: Contraintes et perspectives de la chaîne de valeur, Dans: Reconstruire le potentiel alimentaire de l'Afrique de l'Ouest, A. Elbehri (ed.), FAO/FIDA. 2013;1-38.

3. FAO. FAOSTAT, statistical database; 2015. Available:http://faostat3.fao.org/browse/Q/ QC/E

4. FAO. FAOSTAT, statistical database; 2013.

5. Sanni L, Alenkhe B, Edosio R, Patino M, Dixon A. Technology transfer in developing countries: Capitalizing on equipment development. Journal of Food, Agriculture and Environment. 2007;5(2):88-91.

6. Fagbemissi RC, Coulibaly $\mathrm{O}$, Hanna R, Endamana D. Adoption de variétés de manioc et efficacité durable de la lutte biologique contre l'acarien vert du manioc au Bénin. Bulletin de la Recherche Agronomique du Bénin. 2002;38:1-17.

7. FAO. FAOSTAT, statistical database; 2014. Available:http://faostat3.fao.org/browse/Q/ QC/E

8. Lozano J, Terry C. Cassava diseases and their control. In: Proceedings of the $4^{\text {th }}$ Symposium of ISTRC; 1976.

9. Kabeya M. La culture du manioc en tropique et culture de tropique. CAVTK, Kinshasa, DRC. 2004;4-7.

10. Legg J, Aggarwal V, Andrade M, Cherry A, Coulibaly O, Coyne D, Dixon A, Gockowski J, Hanna R, Hell K, James B, Kasele I, Khizzah B, Mahungu N, Whyte J. Integrated management of cassava pests and diseases. 2002;33.

11. Uzokwe Veronica NE, Deusdedit P, Mlay, Habai R, Masunga, Edward Kanju, Inakwu OA, Odeh, Joseph Onyeka. Combating viral mosaic disease of cassava in the Lake Zone of Tanzania by intercropping 
with legumes. Crop Protection. 2016;84: 69-80.

12. Lenli CO. Biology and control stratégies for whitefly (Bemisia tabaci Gennadius) (Homoptera: Aleyrodidae) populations in Burkina Faso (West Africa). McGill University, Montréal, Québec. 2003;219.

13. Njukwe E, Nguenkam A, Mbairanodji A, Ngue-Bissa T, Hanna R. Improving food security and income and enhancing farmers' livelihoods in Cameroon through the introduction and promotion of improved cassava germplasm. Proceedings of the $11^{\text {th }}$ Triennial Symposium of the ISTRC-AB, Kinshasa, DRC, 4-8 October 2010. Okechukwu R. U. and Ntawuruhunga P. (Ed.). 2012;289-292.

14. Forest Savana Sustainability. Symposium Conference by JICA and IRAD Cameroon; 2016.

15. Sarr PS, Shigeru A, Njukw EE. Interactions between cassava varieties and soil characteristics in crop production in Eastern Cameroon. African Study Monographs. 2013;34(4):187-202.

16. Tata Hangy KW, Mahungu NM. Les principales maladies du manioc en République Démocratique du Congo et leurs moyens de luttes. 2014;14-23.

17. Manga GA, Yemefack M, Sarr PS, Omoko $M$, Shiegeru A. Sustainable cassava production in forest zone of Cameroon. Progress Report (FOSAS 3013) 2013;117123.

18. Guthrie John. Contrôler la mosaïque africaine du manioc. Centre Technique de Coopération Agricole et Rurale. 1996;23.

19. Bigirimana S, Legg JP. La menace de la pandémie de la mosaïque du manioc sur la production et ses conséquences au Burundi. Proceedings of the $13^{\text {th }}$ ISTRC Symposium. 2007;359-364.

20. Mogo A, Tagong MWC, Ngonkeu Mangaptche EL, Fomekong JN, Fotso, Woin N. Assessment of tolerance potential of cassava (Manihot esculenta Crantz) Genotypes to Whiteflies (Bemisia tabacl) in East Cameroon. Annual Research \& Review in Biology. 2018;25(4):1-12.

21. Fauquet C, Fargette D, Thouvenel JC. Épidémiologie de la mosaïque africaine du manioc a l'échelle régionale en côte d'ivoire. Laboratoire de Phytovirologie, ORS'IOM, BP. 1998;5(1):121-124.

22. FAO. FAOSTAT, statistical database. Rapport Mondiale de la Production Vivrière. 2010;60.

23. Nkongolo KK, Bragard C. Effect of NPK fertilization on Cassava Mosaic Disease (CMD) expression in a Sub-Saharan African Region. Am. J. Exp. Agric. 2012;2(3):336-350.

24. Braima James, John Yaninek, Peter Neuenschwander, Anthony Cudjoe, Wester Modder, Nnamdi Echendu, Muaka Toko. Lutte contre lesravageurs du manioc. ISBN 978-131-184-3; 2000.

25. Fauquet C, Fargette D. African cassava mosaic virus: Etiology, epidemiology, and control. Plant Disease. 1990;74(6):40044011.

(C) 2018 Mogo et al.; This is an Open Access article distributed under the terms of the Creative Commons Attribution License (http://creativecommons.org/licenses/by/4.0), which permits unrestricted use, distribution, and reproduction in any medium, provided the original work is properly cited.

Peer-review history:

The peer review history for this paper can be accessed here: http://www.sdiarticle3.com/review-history/45119 